Pieter Bevelander and Henrik Emilsson

\title{
One size fits all? Integration approaches for beneficiaries of international protection
}

MIM Working Paper Series 21: 1

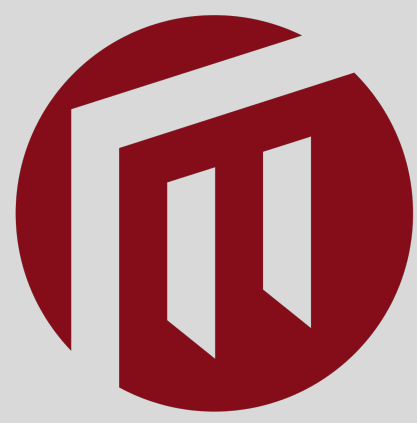




\section{MIM Working Paper Series No 21: 1}

\section{Published}

2021

\section{Editor}

Anders Hellström, anders.hellstrom@mau.se

\section{Published by}

Malmö Institute for Studies of Migration, Diversity and Welfare (MIM)

Malmö University

20506 Malmö

Sweden

ISBN 978-91-7877-174-5 (pdf)

DOI 10.24834/isbn. 9789178771745

Online publication 
Pieter Bevelander and Henrik Emilsson

\section{One Size fits all? Integration approaches for beneficiaries of international protection}

\section{Executive Summary}

International migration and the integration of migrants - in particular persons granted international protection - pose significant challenges for EU Member States. Labour market integration outcomes vary widely among Member States by category of admission and country of origin. Research shows that both supply and demand side factors as well as labour market integration policies are important for inclusion of migrants into the labour market, and overall, into society.

This thematic paper deals with integration policies concerning persons who are granted international protection in EU Member States. It acknowledges that there are two general trends in integration policies - a civic turn and a local turn. The civic turn implies more integration requirements for migrants, decided upon by the state, that have an impact on the legal status of migrant newcomers. On the other hand, the local turn implies less national involvement with cities instead handling more of the integration policies, including funding and policy measures.

The paper then describes four different models for the integration of beneficiaries of international protection: a national government-led model, a project based/multilevel governance model, a laissez-faire model, and a NGO-led model.

Irrespective of the model applied, countries must consider if participation in an integration programme should be voluntary or mandatory, if service delivery should be targeted or mainstreamed, and what the responsibilities are between different government levels. It is clear that Member States face different challenges in service delivery, from basic funding to quality in service delivery. Since countries are different and the number of beneficiaries of international protection varies, no integration model fits all Member States. Nevertheless, all countries would benefit from an integrated approach with better coordination between government levels and between different stakeholders at a local level. 
Key Words

Labour market integration, refugees, introduction programs, integration policy

Bio Notes

Pieter Bevelander is Director of the Malmö Institute for Studies of Migration, Diversity, and Welfare (MIM) and Professor in international migration and ethnic relations (IMER) at the Department of Global Political Studies (GPS) at Malmö University. His research interest includes naturalization and labour market integration, economic integration of refugees arriving via family reunification, and attitudes toward these groups

Henrik Emilsson is Doctor of International Migration and Ethnic Relations at the Department of Global political studies. His main research interests are migration and integration policies, and labour market integration. He has participated in several large European research project in the FP7, AMIF and Horizon 2020 programs, and published and reviewed articles in leading migration journals, such as IMR and CMS.

\section{Contact}

henrik.emilsson@mau.se

This report was written for the Mutual Learning Conference on 'Sustainable inclusion of migrants into society and labour market' organized by the European Commission in cooperation with the Social Protection Committee (SPC), the Employment Committee (EMCO) and Member States' authorities on 12 April 2019 in Brussels. 


\section{INTRODUCTION}

International migration within and to the EU has increased and, consequently, so has the challenge of the economic performance and wider integration of different categories of migrants in Europe. Continuous international migration to Europe is expected to be substantial in the coming decades as well as the slow-moving integration of third country nationals in Member States. This calls for measures to address the effectiveness of policies and programmes currently in place to support the labour market and social inclusion of current and future migrants in Member States. For the receiving society, better labour market integration is beneficial since migrants contribute to the welfare system through taxes, and bring new skills and competences to the host countries. Improved integration of migrants could help to reduce the "integration pessimism" currently being experienced within the European political context.

In the following section, we set the scene with a short overview of migration (including asylum seekers) to Europe, a brief overview of employment integration (as a key indicator for integration) of migrants in EU Member States, and a short overview of the factors identified above affecting labour market integration of migrants and refugees in host countries.

This is followed by a comparison of labour market and social inclusion programmes across Europe. First, we present some trends in Europe when it comes to integration policies and introduce four different models of how countries approach migrant integration. Next, we identify three main policy choices. Last, we highlight the various types of challenges that countries are confronted with in terms of service delivery to persons granted international protection.

This thematic paper ends with a summary of key outcomes of previous mutual learning events, 2016-17, organised by the EU on migrant integration in the EU, and a discussion about integration approaches in relation to different integration models, choices, and challenges.

\section{SETTING THE SCENE}

\section{Migration to the EU}

According to the latest Eurostat report ${ }^{1}$ on Migration and Migrant Population Statistics, about 2.4 million third-country nationals migrated to the EU in 2017. In numbers it meant that Germany received 391000 third country nationals and other countries like the UK received 320 000, Spain 314 000, France 167000 and Italy 240000 third country nationals. Only six EU Member States Bulgaria, Croatia, Latvia, Lithuania, Poland and Romania - experienced net outmigration, with more

\footnotetext{
${ }^{1}$ Internet: https://ec.europa.eu/eurostat/statisticsexplained/index.php?title=Migration_and_migrant_population_statistics
} 
individuals leaving these countries than entering.

A further breakdown into the types of residency permits issued, such as family, education, employment or other, shows that in 2017 over 1 million permits were issued for employment, over 800000 for family reasons, and over 500000 for education-related reasons. Finally, about 750000 permits were issued for other reasons including residency without the right to work and for international protection. ${ }^{2}$ As can be seen in figure 1, the number of first residency permits issued by EU countries has been stable in the period 2008-17. Permits issued for employment have been increasing since 2012 and reached their peak at 1 million in 2017. Clearly not representative for the EU, Poland issued half of the permits for employment with 597000 permits and Ukraine was the non-EU country that received the highest number of residency permits. (21.1\% of all permits).

The total number of non-EU citizens in the resident population of the EU-2 8 countries was 22.3 million in 2018, representing $4.4 \%$ of the total EU-28 population. In the same year, 38.2 million people born outside of the EU-28 were living in an EU Member State. ${ }^{3}$ Another 21.8 million EU citizens, were living in another EU Member State than the one they were born in. (see figure 2 ).

\section{Asylum seekers and beneficiaries of international protection}

A significant share of migration inflow into the EU Member States consists of asylum applicants. However, according to Eurostat Asylum statistics ${ }^{4}$, asylum applications have fallen from 655000 applications in 2017 to 581000 in 2018. This was again a drop from the peak years of 2015 and 2016 (see figure 3). The main reason for this drop was that people from Syria and Nigeria filed lower numbers of applications. Although applications decreased by 21000 applications in 2018 to 81000 (from 102000 in 2017), the highest share of applications for asylum in EU Member States came from citizens of Syria with a share of $14 \%$ of the applications in 2018 . Out of all asylum applications, $7 \%$ were individuals with Afghan and Iraqi citizenship. In addition, figure 4 shows the number of non-EU asylum seekers for the years 2017 and 2018 as well as the countries in which asylum seekers filed their first application. The main countries are Germany, France, Greece, Spain and Italy. Finally, the average percentage of rejected asylum application is more than $60 \%$ in the 28 EU-Members States, but there is large variation across the Member States (see figure 5).

\footnotetext{
${ }^{2}$ Internet: https://ec.europa.eu/eurostat/statisticsexplained/index.php/Residence_permits_statistics\#First_residence_permits:_an_overview

${ }^{3}$ The difference is due to that a substantial number of individuals not born in an EU Member State have obtained citizenship in one of the EU Member States.

${ }^{4}$ https://ec.europa.eu/eurostat/statistics-explained/pdfscache/5777.pdf
} 
In this report, we are primarily discussing integration measures for persons granted international protection. Table 1 shows the number of positive asylum decisions in the EU in 2017-18, and also shows how the numbers are unevenly distributed between Member States. Some large countries, such as Poland, Spain and the UK, receive relatively low numbers, as well as most of the Member States that joined the EU after 2004. Germany and Sweden issued almost $75 \%$ of all positive decisions in 2016, but compared to the period 2015-16, Germany, Sweden, but also Austria and the Netherlands have substantial lower positive decisions for the years 2017 and 2018.

Table 1. Persons granted international protection 2012-2018

\begin{tabular}{|c|c|c|c|c|c|c|c|}
\hline Country & 2012 & 2013 & 2014 & 2015 & 2016 & 2017 & 2018 \\
\hline European Union & 91010 & 107610 & 167385 & 307650 & 672890 & 437555 & 217875 \\
\hline Belgium & 5555 & 6280 & 8045 & 10475 & 15045 & 12585 & 9675 \\
\hline Bulgaria & 170 & 2460 & 7000 & 5595 & 1350 & 1695 & 740 \\
\hline Czechia & 175 & 345 & 375 & 460 & 435 & 145 & 155 \\
\hline Denmark & 1695 & 2810 & 5480 & 9995 & 7125 & 2365 & 1315 \\
\hline Germany & 17135 & 20125 & 40560 & 140910 & 433905 & 261620 & 75940 \\
\hline Estonia & 10 & 10 & 20 & 80 & 130 & 95 & 20 \\
\hline Ireland & 100 & 150 & 400 & 330 & 485 & 760 & 1005 \\
\hline Greece & 95 & 500 & 1970 & 4030 & 2715 & 10455 & 15210 \\
\hline Spain & 525 & 535 & 1585 & 1020 & 6855 & 4090 & 2895 \\
\hline France & 8645 & 10705 & 14815 & 20630 & 28755 & 32565 & 33195 \\
\hline Croatia & 20 & 25 & 25 & 40 & 100 & 150 & 135 \\
\hline Italy & 22025 & 14390 & 20580 & 29615 & 35405 & 31795 & 30670 \\
\hline Cyprus & 105 & 165 & 995 & 1585 & 1300 & 1245 & 1215 \\
\hline Latvia & 25 & 25 & 25 & 20 & 135 & 265 & 30 \\
\hline Lithuania & 55 & 55 & 70 & 85 & 195 & 285 & 135 \\
\hline Luxembourg & 40 & 130 & 120 & 185 & 765 & 1125 & 1000 \\
\hline Hungary & 350 & 360 & 510 & 425 & 430 & 1290 & 365 \\
\hline Malta & 1435 & 1605 & 1260 & 1250 & 1190 & 760 & 645 \\
\hline Netherlands & 5505 & 5965 & 12550 & 16450 & 20810 & 7810 & 3620 \\
\hline Austria & 4455 & 4920 & 7175 & 15045 & 30370 & 25200 & 15020 \\
\hline Poland & 520 & 685 & 720 & 640 & 295 & 510 & 375 \\
\hline Portugal & 100 & 135 & 110 & 195 & 320 & 500 & 625 \\
\hline Romania & 230 & 915 & 740 & 480 & 805 & 1245 & 595 \\
\hline Slovenia & 35 & 35 & 45 & 45 & 170 & 150 & 100 \\
\hline Slovakia & 190 & 70 & 170 & 80 & 210 & 60 & 45 \\
\hline Finland & 1555 & 1650 & 1270 & 1680 & 7070 & 3430 & 2405 \\
\hline Sweden & 12400 & 24015 & 30650 & 32360 & 66585 & 26775 & 10640 \\
\hline United Kingdom & 7845 & 8550 & 10120 & 13950 & 9935 & 8570 & 10100 \\
\hline
\end{tabular}

Source: Eurostat 


\section{Labour market integration}

One of the key migrant integration indicators is the extent to which migrants have obtained employment and how this level compares to the native population. Since many migrant integration policies focus on the first step into the labour market, it is also a crude indicator of the effectiveness of the labour market integration programmes/policies. Current statistics on the native-migrant employment gap in EU Member States indicate that there is a persistent native-migrant employment gap; in 2017 this was $5.9 \%, 2.4 \%$ for males and $8.8 \%$ for females. However, when splitting the foreign born group into EU born versus non-EU born, EU born males and females have higher employment rates than native born males and females which clearly shows that non-EU born have substantially lower employment rates than both native born and EU born migrants. This overall gap is primarily due to the low employment level of non-EU born women (see figure 6). ${ }^{5}$

Descriptive research has identified four clusters of EU countries with similar employment gaps between natives and migrants: 1) countries with a native-migrant employment gap between 15-20\% which to a large extent have had refugee migration, 2) countries with longstanding migration which have a native-migrant employment gap between 10-15\%,3) countries with more recent migration where there is no native-migrant employment gap, or it favours migrants, and 4) countries with primarily border migration from neighbouring countries where there is no employment gap between natives and migrants (Grubanov-Boskovic et al. 2017) (see figure 7$)^{6}$

A key limitation in the descriptive yearly information on employment or other integration indicators is that "integration" is pictured as a static state, which is generally not the case for the individual or the migrant group or indeed for the receiving labour market.

Figure 8 is an example of how employment integration changes over time for different cohorts of refugee groups in the Swedish labour market. The figure shows both the employment rate over time for male and female refugees and presents some interesting patterns. First, two groups, one with higher (individuals from Bosnia, Eritrea, Ethiopia), and one with lower (individuals from Afghanistan, Iran, Iraq, Somalia, Syria) employment levels, seem to prevail in both figures while being more marked among women. Second, for all origin groups (except Ethiopia), the initial female employment shares were lower than those of their male counter parts. Besides,

\footnotetext{
${ }^{5}$ Internet: https://ec.europa.eu/eurostat/statistics-explained/pdfscache/35409.pdf

${ }^{6}$ Country clusters: 1) Denmark, Finland and Sweden, 2) Austria, Belgium, France, Germany, Luxembourg, the Netherlands and United Kingdom, 3) Cyprus, Greece, Ireland, Italy, Malta, Portugal and Spain, 4) Bulgaria, the Czech Republic, Estonia, Hungary, Latvia, Lithuania, Poland, the Slovak Republic and Slovenia.
} 
all groups have increasing employment levels with increased time in the country. For men from Bosnia, Ethiopia and Eritrea, employment growth plateaus approximately six years after migration. For women from Bosnia, Ethiopia and Eritrea this plateau is reached after about 8 to years after migration. Among the men, only the employment share of Bosnian men who entered Sweden as refugees decreases from the seventh year after migration. The same pattern can be observed for Syrians at a much lower employment level. For male refugees from Iraq, Iran and Afghanistan, growth is slower but continues until the twelfth year since they migrated; for their counterparts from Somalia, the growth stagnates after 2 to 4 years in the country. Women from Afghanistan, Iran, Iraq, Somalia, Syria start at a very low employment levels in the first years after migration but subsequently increase their levels with more years in the country. Similar heterogeneous employment integration patterns are found in the Netherlands (de Vroome and van Tubergen, 2010; Bakker et al. 2013), Denmark (Schultz-Nielsen 2017), Norway (Bratsberg et al. 2017).

In summary, varying employment patterns across different migrant groups in different EU Member States underscore the complexity for the inclusion of migrants in the labour market and other societal domains, and presents challenges for policy makers working to improve integration.

\section{Explaining labour market integration}

From an economic perspective, labour market integration of migrants can be influenced by supply-side factors such as migrant skills and qualifications or by the opportunities and restrictions on the demand-side such as labour market needs, and migration and integration policies in the receiving country. One of the standard propositions in the economic migration literature is that migrants tend to be favourably self-selected ${ }^{7}$ on the basis of their skills, health and other traits. In addition, compared to migrants who have been selected on the basis of their skills and qualifications, non-economic migrants, such as family reunion migrants, and refugees, are not primarily selected on these characteristics, which leaves them in a more vulnerable position in the labour markets of receiving countries (Chiswick 2000).

A number of studies in the US (Connor 2011), Canada (Aydemir 2011), the UK (Bloch 2007), the Netherlands (de Vroome and van Tubergen, 2010; Bakker et al. 2013), Denmark (Schultz-Nielsen 2017), Norway (Bratsberg et al. 2017) and Sweden (Bevelander and Pendakur 2014) have specifically focused on the labour market integration of refugees. This research shows that, compared to other migrant categories, refugees generally have lower employment rates, particularly soon after their arrival in the host country. Therefore, a number of countries have introduced

\footnotetext{
${ }^{7}$ Self-selection mean that individuals who migrate are a selection of individuals from a population and have other observed or unobserved characteristics from this population.
} 
integration policies that enhance refugee labour-market integration. However, it is noteworthy that very few refugee integration policies have been evaluated. The fact that refugees arrive under different, and often difficult circumstances, have not primarily migrated for labour-market reasons and are admitted according to other (non-economic) criteria appears to affect the rate and success of their integration into the labour market. Moreover, as both the migration and the admission processes can be lengthy and cumbersome, health issues and the loss of human capital can hinder individuals' adaption to the labour market of a new country (Dustmann et al. 2017). Whether refugees and family-reunion migrants obtain permanent or temporary residence creates uncertainty about the future and can affect their investment in the host language, obtaining-country-specific human capital and their labour-market integration process (Hainmueller et al. 2016).

A number of specific surveys have been carried out that support the relationship between migrant admission category and economic outcomes. In the case of the Netherlands, de Vroome and van Tubergen (2010) found that host-country-specific education, work experience, language proficiency and contacts with natives were positively related to the likelihood of obtaining employment and occupational status. In another study on the Netherlands, Bakker et al. (2013) showed that post-migration stress or trauma affects refugees' labour-market integration. Survey data for the United Kingdom point to the fact that policies which restrict access to the labour market reduce opportunities and have a negative impact on refugees' employment probabilities (Bloch 2007).

For Canada, Aydemir (2011) estimates that refugees have lower participation rates than family-reunion migrants, but that their earnings are about the same. Assessments of economic outcomes in the United States have shown that refugees have lower earnings than other admission categories but that this difference can at least partially be explained by differences in language ability, education, levels of family support, mental health and residential area. However, a gap remains even after controlling for these factors (Connor 2010). Studies for Norway and Denmark show that refugees and family members have an initial promising increase in labour-market integration but a subsequent levelling out and even a reverse process after about 10 years (Bratsberg et al. 2017; Schultz-Nielsen 2017). These studies underscore the heterogeneity within admission categories and country-of-origin schooling as explanatory factors for labour-market success.

Most of these studies were conducted in single countries and therefore lack comparative perspective of different reception contexts. Bevelander and Pendakur (2014) conducted a comparative study of the economic integration of the same admission categories (asylum migrants, resettled refugees and family reunion migrants) and country of origin groups in Sweden and Canada. They reported that, after controlling for other variables, the probability of being employed was roughly the same in Canada and Sweden; however, there was a difference in earnings between the 
two countries, being higher in Canada. Differences between admission categories were smaller in Sweden than they are in Canada. The authors argued that this could be due to the fact that in Sweden all these categories were entitled to receive the same services and to participate in the same introduction programmes, whereas in Canada only resettled refugees had access to such services and programmes.

Overall, the majority of the studies cited above conclude that refugees are in a disadvantaged position when it comes to integrating into the labour markets of receiving countries. However, there are also discrepancies among such studies: while some report that the performance of refugees is comparable to that of other migrants, others argue that the differences between them are substantial. Important factors that have been highlighted explaining the lower labour market integration of refugees are, poor mental health, long waiting periods during asylum and indecisiveness about duration of stay, level of education and skills and integration programs.

\section{COMPARISON OF THE LABOUR MARKET AND SOCIAL INCLUSION PROGRAMMES ACROSS EUROPE}

Policies of migrant integration share the aim of steering and guiding the integration process in a more favourable direction. Even though the Qualifications Directive (2011/95/EU), Race Equality Directive (2000/43/EC) and Employment Equality Directive (2000/78/EC) set some binding minimum standards, the EU-integration policy is mostly governed by guidance and support through the European Agenda for Migration and the Action Plan on the integration of third country nationals. Integration policies are therefore largely designed and implemented by the Member States themselves, influenced by differences in social and political systems, the organisation of the welfare states, the historical and cultural characteristics of the host countries and their migration experiences (Gregurović \& Župarić-Iljić, 2018). However, as the Qualifications Directive implies, persons granted international protection could, in comparison to other migrant groups, have special needs that have to be taken into account in every Member State. Integrated approaches where different government levels and local stakeholders cooperate and coordinate measures could be beneficial for the individual and cost efficient for the receiving society. How such approaches can be advanced in countries with different preconditions is discussed in section 5. First, we present some trends in Europe when it comes to integration policies and introduce some different 'models' in how countries' approach migrant integration. Next, we identify three main policy choices. Last, we highlight the various ways in which countries confront different challenges in service delivery to persons granted international protection. 


\section{General trends in integration policies}

Countries' integration policies are based on different philosophies, include different policy measures and are governed differently (see below for differences). There are also forces that push integration policies to converge, such as the open method of coordination in the EU and policy diffusion ${ }^{8}$ between Member States. Researchers have identified two major trends in integration policy-making; a civic turn and a local turn. These two policy trends seem to contradict each other; the civic turn implies more requirements for migrants that are decided at the national level and have an impact on the lives of migrant newcomers. On the other hand, the local turn would imply less national involvement, with cities handling more of the integration policies.

A relatively new feature is the introduction of civic integration programmes, often consisting of language training and civic orientation (Goodman, 2010, 2012a, 2012b). Successful participation in those programmes are often a requirement for access to long term or permanent residence and/or citizenship. Civic integration policies are also part of the migration control, forcing migrants to fulfil certain requirements in order to stay in the country and be joined by their family members for family reunion or family formation. The Dutch Newcomers Act of 1998 is often seen as the first example of civic integration policies, but there have been many followers. Other countries like Denmark, Germany, Austria, Netherlands, UK and France have introduced many civic integration policy instruments between 1997 and 2009 (Goodman 2010).

Austria, Flanders in Belgium, the Czech Republic and France have made it mandatory to pass a level A in the Common European Framework of Reference for Languages ${ }^{9}$ in order to obtain permanent residence while B1 level has to be completed in Austria, Estonia and France in order to acquire citizenship (European Migration Network, 2019). The introduction of such requirements has shifted the burden of adjustment towards the individual migrant. The underlying aim is generally to promote individual autonomy and common values for newcomers (Groenendijk et al., 2009; Joppke, 2007).

\footnotetext{
${ }^{8}$ The idea that the policy choices made in a given place and time are influenced by the policy choices made elsewhere.

${ }^{9}$ Read more about the Common European Framework of Reference for Languages here: https://www.coe.int/en/web/common-european-framework-reference-languages/level-descriptions
} 
Many researchers have also identified a local turn in integration policies where local governments, large cities in particular, are becoming increasingly entrepreneurial in developing their own integration philosophies and policies (Scholten \& Penninx, 2016; de Graauw \& Vermeulen, 2016). Thus, local governments do not just implement national policies, but are policy makers as well (Alexander $2003 \& 2007$; Penninx et al. 2004; Penninx 2009; Caponio \& Borkert 2010). See 4.2 for a discussion about the state and local level

\section{COMPARATIVE BACKGROUND OF INTEGRATION APPROACHES}

There have been efforts to compare integration measures between countries, including EU Member States. The Migrant Integration Policy Index (MIPEX) is one example. In the context of integration for persons granted international protection, MIPEX has two shortcomings. Firstly, it does not focus on integration policies for this specific target group. Secondly, it does not really study integration policies and measures, but rather focuses on countries' progress in equalising the rights of migrants with the rights of natives (Goodman, 2010). For example, recognised refugees and beneficiaries of international protection are entitled to labour market and social support under the same terms as natives in Greece, Hungary and Italy, but there are few targeted labour market measures which means that services could be difficult to access (DirectorateGeneral for Internal Policies, 2017). One promising comparative project is 'The National Integration Evaluation Mechanism (NIEM)' project that is developing an integration policy index especially for persons granted international protection. The project is expected to deliver its first report in spring/summer 2019. We should, however, be careful not to equate integration policies with integration outcomes. Some studies show that the correlation between integration policies and integration outcomes are weak and sometimes counter to expectations (Koopmans, 2010), and depend more on the composition of the migrant group (Luik, Emilsson \& Bevelander, 2018).

Countries' integration policy differs when it comes to underlying ideology, what measures and services they offer and governance strategies. The next section looks at the model used in Scandinavia, and then compares it to other countries.

National government-led model: Denmark, Norway and Sweden

\section{National government-led model: Denmark, Norway and Sweden}

In a European perspective, the Scandinavian introduction programmes share many similarities (Hernes \& Rose Tronstad, 2014). They primarily rely on efforts from the national level (funding and services) and local level (services) with the involvement of civic organisations and social partners to some degree. Almost all persons granted international protection participate in full-time activities for two to three years. 
Programme activities include language training, civic orientation and other measures to ease access to the labour market. The public sector is the main actor in all Scandinavian countries, but the formal responsibilities differ. In Sweden, it is the Employment Service, a state agency, that coordinates the program and deliver labour market activities while the local municipalities are responsible for language training, civic orientation and adult education. Labour market activities can include the validation of skills and recognition of existing qualifications, labour market education, general adult education, on the job training, or subsidised employment. Individual plans are made to tailor the services to individual needs and recommended actions favour parallel courses with a combination of language and on-the-job training, rather than a sequential setup where the language programme has to be completed before work-related programmes.

The difference between the Scandinavian programmes is whether participation is voluntary or a requirement (Borevi, Jensen \& Mouritsen, 2017; Hernes \& Rose Tronstad, 2014). In Norway and Denmark, programme participation may affect the assessment of applications for permanent residence, insofar as people are required to participate in (Norway) or to have passed exams in (Denmark) language training and civic orientation. In Sweden the introductory programme is only an entitlement, even though non-participation may also lead to economic sanctions, as it does in Denmark and Norway.

There are many advantages of a state funded introduction programme that covers all persons granted international protection. The most obvious is access to services; during 2017, more than 75000 persons were enrolled in the Swedish introduction programmes and had access to a range of different services. The programmes have been stable and both vertical and horizontal coordination has improved over time. One important instrument is the local and regional agreements to improve collaboration, signed by important stakeholders such as County Administrative Boards, Swedish Social Insurance Agency, Migration Board, Employment Service, regional and local municipalities, universities and NGOs. The downside is that the introduction programmes are expensive, the actual labour-market integration is sluggish, and there are only a limited number of introduction measures that are proven to be effective. Lock-in effects, where participants prefer staying in a program over making their own choices, are also a risk (Bevelander \& Emilsson, 2016). Thus, the good practice of the Scandinavian approach is more a question of the general access to services and resources for migrant newcomers.

\section{Project based/multi-level governance model: Austria and Germany}

Austria and Germany are countries that are considered to have a project-based, or a multi-level approach to integration (Joyce, 2018; Scholten et al, 2017). Because integration measures are both project-based and more long-term, and initiated and 
funded at many government levels, the model differs from state-led models. In both countries, integration measures are developed at the local and regional level, but over time the national level has increased their involvement (Scholten et al, 2017). Today, in Germany many beneficiaries of international protection have access to language training and civic orientation courses through state funded programmes (designed and funded by Bundesagentur für Migration und Flüchtlinge (BAMF) and provided by civic organisations and private language schools) while the access to other services differ between cities and Länder (Joyce, 2018). During the 2015-16 'refugee crisis' both Austria and Germany organised many new specific projects. Austria increased the state budget for integration to set up German courses, competence checks by the Public Employment Service, a voluntary integration year, mentoring programmes, and nationwide apprenticeship placement (Mara, Vidovic \& Windisch, 2016). In Germany most of the sixteen Bundesländer and many local governments launched their own programmes in response to increasing numbers, such as language courses and early skills and needs assessment (Aumüller, 2016). Compared to the Scandinavian model, the national level in Austria and Germany is not as dominant. Policy initiatives and measures are often developed at different government levels and there are considerable local variations in service delivery.

\section{Laissez faire model: United Kingdom, the Netherlands and Italy}

In some countries, state level involvement in integration services are almost absent. The Italian government has slowly moved from an emergency approach, providing first assistance to those arriving in Italy, to a more structured approach which provides tailored support to the person who has asked for international protection. However, services are still mostly dependent on cooperation between local governments and NGOs (Venturini, 2016). In the Netherlands, the state level has withdrawn most public integration services, although they fund some NGOs. Persons granted international protection must pay for their own integration courses (language and civic orientation) that are provided by more than 200 private companies, language schools and civic organisations that are authorised and ranked by a public agency (Joyce, 2018). Dutch municipalities have a great deal of autonomy in choosing which type of labour market assistance they wish to provide. The UK Government stepped back from a national integration strategy in 2010, and instead funds some small projects in multilevel governance with NGOs and local governments (Scholten et al, 2017). Thus, local governments have considerable power to set their own integration strategies. However, as a response to the 'refugee crisis', UK in 2016 set up the Syrian Vulnerable Persons' Resettlement Scheme (VPRS) and the Vulnerable Children's Resettlement Scheme (VCRS) that includes some state funded integration services. 


\section{The NGO model}

In many countries, there are still no resources or infrastructure for integration on either the local, regional, or national level. Some countries in Central Eastern Europe belong to the NGO model'. Those countries share the feature of being heavily dependent on EU-funding, especially The Asylum, Migration and Integration Fund (AMIF), with NGOs as main service providers. For example, all projects promoting integration in Hungary 2017 were run by NGOs (Directorate-General for Internal Policies, 2017).

\section{POLICY CHOICES}

Independently of what models of integration we find currently in Europe, countries must consider if it should be a voluntary or a mandatory requirement to participate in integration programs, if service delivery should be targeted or mainstreamed, and what the responsibilities are between different government levels.

\section{Voluntary or required participation in integration programs}

In the Scandinavian model we have shown that access to services is good and similar in Sweden, Norway, and Denmark, but that there are big differences in the degree of integration requirements for accessing long term residence permits and citizenship. Accroding to Lutz (2017) the degree of requirements that migrants must fulfil depends on the underlying logic of policy interventions (what he calls a logic of conditioning and a logic of enabling), or in other words, establishing whether the policy interventions are based on an incentive-based theory or an opportunity-based theory. Moreover, there is no clear evidence to indicate whether integration requirements improve integration outcomes or not. However, the main problem with integration requirements is when there are only a few opportunities to meet certain requirements in place. For instance, countries such as the Netherlands and the United Kingdom have requirements, but provide little public support to persons granted international protection to help them meet the requirements. Scholten et al (2017) define such countries as having a differentialist approach, where measures are put in place to restrict opportunities for integration.

\section{Targeted approaches and mainstreaming approaches}

A way to categorise integration measures/programmes is to differentiate between mainstreaming and targeted approaches, although some countries like Sweden combine the two approaches.

Mainstreaming approaches have the overall objective to provide and improve access to mainstream services by fostering relevant policy measures that target all residents or all those needing integration, while services are required to adopt a non- 
discrimination and diversity policy.

Targeted approaches consist of (sometimes mandatory) integration programmes with civic orientation and language courses, and other kinds of integration support customised to specific groups. Targeted approaches can be temporary and projectbased as well as firmly institutionalised.

When the European Migration Network (2019) made a summary of integration approaches in the EU Member States, they considered that eight countries ${ }^{10}$ have a mainstreaming approach, five ${ }^{11}$ have a targeted approach and three ${ }^{12}$ have no approach.

\section{State versus local integration policies}

As we have seen in the previous section, some countries have a state-centric top-down integration policy. Sweden and Norway are clear examples where integration programmes are carried out on the local level by state and local level public agencies, but they are funded and regulated by the state.

Looking only at who delivers most of the services for migrant newcomers, the European Migration Network (2019) distinguishes between centralised ${ }^{13}$ and decentralised ${ }^{14}$ models. In the centralised model, responsibilities tend to be concentrated in one or two ministries, some with specialised consultative bodies, whereas in decentralised structures responsibilities in implementing policies are spread across federal/regional and local authorities. It would be wrong, however, to equate decentralised models with less state level involvement. Sweden and other Scandinavian countries have, for example, a decentralised service delivery shared between municipalities and national agencies. The responsibility for policies and funding are however, located at national level.

Countries such as Austria and Germany have a shared responsibility between government levels, a so-called multi-level governance approach. The UK, Italy, Belgium and the Netherlands are examples of localist decentralised approaches. Integration policies are left to the local level to design and implement, often in cooperation with NGOs, and often with funding from the EU. Countries could also be considered to have no approach. Some countries in Southern Europe and many countries in Eastern Europe are completely reliant on NGOs and EU-funding.

\footnotetext{
${ }^{10}$ AT, DE, ES, IE, NL, LU, SE, UK

${ }^{11} \mathrm{BE}, \mathrm{FI}, \mathrm{FR}, \mathrm{IT}, \mathrm{MT}$

$12 \mathrm{CY}, \mathrm{HR}, \mathrm{PL}$

13 BG, CY, CZ, FR, HU, LT, LV, MT

${ }^{14} \mathrm{AT}, \mathrm{BE}, \mathrm{DE}, \mathrm{ES}, \mathrm{FI}, \mathrm{IE}, \mathrm{IT}, \mathrm{NL}, \mathrm{PT}, \mathrm{SE}, \mathrm{SI}, \mathrm{UK}$
} 


\section{DIFFERENT CHALLENGES IN SERVICE DELIVERY}

Service delivery challenges tend to differ greatly between countries. For instance, problems relating to language courses can be related to availability, quality, teaching methods, adaptability and learning outcomes. In the EMN report (2019), Austria, for example, reported the challenge of accommodating third country nationals' diverse educational backgrounds during language acquisition. In Belgium, Estonia and Latvia, waiting lists to access language courses were long. In other countries such as Sweden, access to language training is excellent but overall outcomes are perceived as disappointing.

There seems to be major challenges on two different levels when it comes to service delivery.
A. Funding and access to services.
B. Quality of services and integration outcomes.

The first problem is access to services. Access is an issue in many countries where there is low funding (many southern and eastern EU-countries). Migrants in many Southern and Eastern European Member States often rely on services delivered by NGOs and financed by the EU. In other countries, such as the UK and Ireland, state funding is available, but the service delivery is fragmented and lacks organisational structure, which as a result adversely affects access to services.

Countries that invest more into language programmes and other services are more concerned about the quality and integration outcomes. In Scandinavian countries, as well as in Austria and Germany, the problem related to language training seems to be teacher competences, adapting the training to different needs, and better coordination between language training and labour market programmes.

A recent report (EMN, 2019) identified current challenges in EU Member States in the design and implementation of integration programmes. Many countries consider language courses and recognition of skills and qualifications as problems and also report problems with organisation, such as a lack of coordinated state strategies and lack of tailored approaches to specific groups.

\begin{tabular}{|l|l|}
\hline Problem areas & Countries \\
\hline Language courses & $\begin{array}{l}\text { AT, BE, FI, FR, HU, IE, LV, LT, MT, } \\
\text { PL, SE }\end{array}$ \\
\hline Recognition of skills and qualifications & BE, DE, ES, FI, FR, HU, IE, LV, PL \\
\hline $\begin{array}{l}\text { Adopting a tailored approach adapted } \\
\text { to the specific needs of some groups }\end{array}$ & BE, EE, FI, FR, IE, IT, LV, PL \\
\hline $\begin{array}{l}\text { Restrictive access to work permits for } \\
\text { third country nationals with a residence } \\
\text { permit for the purpose of family }\end{array}$ & HR, IE \\
\hline
\end{tabular}




\begin{tabular}{|l|l|}
\hline reunification & \\
\hline $\begin{array}{l}\text { Lack of a state strategy or lack of an } \\
\text { institutional coordination mechanism }\end{array}$ & BE, BG, HR, FI, IE, IT, LT, LV \\
\hline $\begin{array}{l}\text { Involving employers and employers' } \\
\text { organisations. }\end{array}$ & BE, ES, LU \\
\hline $\begin{array}{l}\text { Lack of a structured funding } \\
\text { framework }\end{array}$ & EL, FI, IE, LT, LV \\
\hline
\end{tabular}

\section{DISCUSSION AND CONCLUSION}

International migration and the integration of migrants, in particular persons granted international protection, is a highly debated issue in many EU Member States irrespective of how many individuals are received. Research on labour market entry over the last decade shows that on the supply side individual characteristics like educational level and reason for migration are important factors explaining labour market entrance. On the demand side, the labour market structure of the receiving in these factors across Member States inevitably result in substantial differences in the extent of challenges faced by Member States and the extent and types of integration policies and practices used.

Key outcomes from earlier mutual learning events organised by the EU recognise that inclusion of migrants is multi-faceted and encompasses several societal domains like housing, education, the labour market, healthcare, etc. It underscores the importance of early activation of asylum seekers/refugees through integrated approaches focussing on individual needs and skills, as well as the importance of specific employment services, educational/vocational education system, NGOs and potential employers. Effective monitoring and evaluation of the effectiveness of the measures and practices is important for upscaling, as well as for improving or abolishing measures. Specific policies to address the needs of women, children and victims of torture should be considered. Costs of integration measures should be seen in relation to the likely predicted costs of non-integration and investment in future labour market and societal inclusion, and this needs to be communicated to wider society.

One model does not fit all countries. Both mainstreaming and laissez faire approaches have one major weakness, namely that they do not take account of the specific nature of the needs that may arise for persons granted international protection. For instance, the OECD (2016) has identified a need for an integration policy that differentiates between refugees and other migrants, as well as between different refugee groups. Targeted interventions and project-based responses could be sufficient and even beneficial when Members States receive small numbers of individuals in order to ensure an integrated response to specific needs. On the other hand, countries with consistently large numbers of persons granted international protection could benefit 
from a permanent infrastructure and mainstream policies adapted to diverse needs.

It is also important that integration policies reflect the context in which they are used. Policies designed for a particular place and target group may not be effective in another city, country or policy area. In this respect, differences in welfare states and labour market regulations must also be considered (Scholten et al, 2017). In countries with more regulated labour markets and higher minimum wages such as Germany, Austria and the Scandinavian countries, barriers to employment tend to be higher than in less regulated economies. As a consequence, there is increased pressure in the former countries to introduce specific policies to help people to access and sustain employment, whereas in countries with less regulated economies a laissez faire approach expects that refugees are able to find their way into the economy by themselves.

In relation to the discussion above, targeted approaches leading to "good" examples of integration policies are often identified from single successful projects in a particular context (and even particular group). For the Scandinavian model, which is designed for the entire target group and as part of a long-term policy, it is difficult to identify its effectiveness in relation to migrants given that most individuals trying to access the labour market, if not all, are treated with similar interventions. In general, it is difficult to evaluate the effectiveness of project outcomes in this context since the effects could be due to factors such as increased resources and higher access to services, and not by the method(s) used.

What is clear from this compilation is that one of the biggest challenges in many EU Member States regarding integration policies to migrants and persons granted international protection is the access to services. Little or few dedicated resources (e.g. use of EU funding only) may lead to limited and fragmented services to migrants and people granted international protection. Even without evaluations, it can be concluded that this is disadvantageous for integration. An important role for the EU is therefore to refer to the commitments made in its Qualifications Directive to support and subsidise EU Members States to implement basic services to migrants and persons with international protection.

Other EU Member States with well-developed policies towards migrants and persons with international protection need to be aware of the continuous nature of change in this area of policy and adapt their policies in relation to changes circumstances, either fluctuations in size or nature of migrant groups, as well as changes in society and the economy in particular. Constant development of approaches to meet these changes as well as the need to increase the effectiveness of policies for integration of migrants are important recommendations for the EU Member States. Even though policy effectiveness is notoriously difficult to prove, some conclusions can be drawn. Experiences from Sweden show that measures with closer connections to the labour market, such as vocational language training and subsidised employment, have more positive outcomes on employment possibilities compared to 
standard language training where it has proven difficult to find any positive effects compared to non-participants and/or drop outs (Emilsson, 2014). 


\section{LIST OF REFERENCES}

Alexander, M. (2003). Local Policies Toward Migrants as an Expression of HostStranger Relations: A Proposed Typology, Journal of Ethnic and Migration Studies, 29(3), 411-430.

Alexander, M. (2007). Cities and Labour Immigration: Comparing Policy Responses in Amsterdam, Paris, Rome and Tel Aviv, Aldershot: Ashgate.

Aumüller, J. (2016). Case Study Germany, in Martin, I. et al, From Refugees to Workers: Mapping Labour Market Integration Support Measures for AsylumSeekers and Refugees in EU Member States, Bertelsmann Stiftung and European University Institute.

Aydemir, A. (2011). Immigrant selection and short-term labor market outcomes by visa category, Journal of Population Economics, 24(2), 451-475.

Bakker, L., Dagevos, J. \& Engbersen, G. (2013). The importance of resources and security in the socio-economic integration of refugees: a study on the impact of length of stay in asylum accommodation and residence status on socio-economic integration for the four largest refugee groups in the Netherlands, Journal of International Migration and Integration, 15(3), 431-448.

Bevelander, P. \& Pendakur, R. (2014). The labor market integration of refugee and family reunion immigrants: a comparison of outcomes in Canada and Sweden, Journal of Ethnic and Migration Studies, 40(5), 689-709.

Bevelander, P \& Luik, M. A. (2020) Refugee Employment Heterogeneity in Sweden: Evidence form a Cohort Analyis, Frontiers in Sociology, doi: 10.3389/fsoc. 2020.00044

Bevelander, P. \& Emilsson, H. (2016). Case Study Sweden, in Martin, I. et al, From Refugees to Workers: Mapping Labour Market Integration Support Measures for Asylum-Seekers and Refugees in EU Member States, Bertelsmann Stiftung and European University Institute.

Bloch, A. (2007). Refugees in the UK Labor Market: The Conflict between Economic Integration and Policy-Led Labor Market Restriction, Journal of Social Policy, $37(1), 21-36$.

Borevi, K., Jensen, K. K., \& Mouritsen, P. (2017). The civic turn of immigrant integration policies in the Scandinavian welfare states, Comparative Migration Studies, 5(9), 1-14.

Bratsberg, B., Raaum, O. \& Røed, K. (2017). Immigrant labor market integration across admission classes, Nordic Economic Policy Review 2017, 17-54.

Caponio, T. \& Borkert, M. (2010). The Local Dimension of Migration Policymaking, Amsterdam: Amsterdam University Press.

Chiswick, B. R. (2000). Are immigrants favorably self-selected? An economic analysis. In Brettell, C. \& Hollifield, J .F. (eds.) Migration theory: Talking across disciplines, New York: Routledge, 61-76. 
Connor, P. (2010). Explaining the refugee gap: economic outcomes of refugees versus other immigrants', Journal of Refugee Studies, 23(3), 377-397.

De Graauw, E. \& Vermeulen, F. (2016). Cities and the Politics of Immigrant Integration: A Comparison of Berlin, Amsterdam, New York City, and San Francisco, Journal of Ethnic and Migration Studies, 42(6), 989-1012.

De Vroome, T. \& van Tubergen, F. (2010). The employment experience of refugees in the Netherlands, International Migration Review, 44(2), 376-403.

Dustmann, C., Fasani, F., Frattini, T., Minale, L. \& Schönberg, U. (2017). On the economics and politics of refugee migration, Economic Policy, 32(91), 497-550.

Directorate-General for Internal Policies (2017). Integration of Refugees in Greece, Hungary and Italy: Comparative analysis, European Parliament.

Emilsson, H. (2014). No Quick Fix: Policies to Support the Labor Market Integration of New Arrivals in Sweden, Washington, DC and Geneva: Migration Policy Institute and International Labour Office

European Migration Network (2019). Labour market integration of third-country nationals in EU Member States - Synthesis Report. Brussels: European Migration Network.

Ferrie, J. P. \& Hatton, T. J. (2015). Two centuries of international migration, in Chiswick, B. and Miller, P. (eds.) Handbook of the Economics of International Migration, Amsterdam and Oxford: Elsevier, 53-88.

Gebhardt. D. (2015). When the state takes over: civic integration programmes and the role of cities in immigrant integration, Journal of Ethnic and Migration Studies, 42(5), 742-758.

Goodman, S. W. (2010). Integration Requirements for Integration's sake? Identifying, Categorising and Comparing Civic Integration Policies, Journal of Ethnic and Migration Studies, 36(5), 753-772.

Goodman, S. W. (2012a). Fortifying Citizenship: Policy Strategies for Civic Integration in Western Europe, World Politics, 64(4), 659-698.

Goodman, S. W. (2012b). Measurement and Interpretation Issues in Civic Integration Studies: A Rejoinder, Journal of Ethnic and Migration Studies, 38(1), 173-186.

Gregurović, S., \& Župarić-Iljić, D. (2018). Comparing the Incomparable? Migrant Integration Policies and Perplexities of Comparison, International Migration, 56(3), 105-122.

Grubanov-Boskovic, S., Natale, F., Scipioni, M. (2017) Paterns of immigrants' integration in European Labour Markets, http://publications.jrc.ec.europa.eu/repository/bitstream/JRC108495/pdf__kcmd_employment_rates.pdf

Hainmueller, J., Hangartner, D. and Lawrence, D. (2016). When lives are put on hold: lengthy asylum processes decrease employment among refugees, Science Advances, 2(1), 1-7.

Hernes, V. \& Rose Tronstad, K. (2014). Komparativ analyse av introduksjonsprogram 
i Norge, Sverige og Danmark, NIBR-rapport 2014:19, Norsk institutt for byog regionforskning.

Joyce, P. (2018). Inspiration for integration. Labour market policies for refugees in five Northern European countries, Ratio Working Paper No. 308, Ratio.

Koopmans, R. (2010). Trade-Offs between Equality and Difference: Immigrant Integration, Multiculturalism and the Welfare State in Cross-National Perspective, Journal of Ethnic and Migration Studies, 36(1), 1-26.

Luik, M. A., Emilsson, H. \& Bevelander, P. (2018). The male immigrant-native employment gap in Sweden: migrant admission categories and human capital, Journal of Population Research, 35(4), 363-398.

Lutz, P. (2017). Two logics of policy intervention in immigrant integration: an institutionalist framework based on capabilities and aspirations, Comparative migration studies, 5(1), 1-18.

Mara, I., Vidovic, H. \& Windisch, M. (2016). Case Study Austria, in Martin, I. et al, From Refugees to Workers: Mapping Labour Market Integration Support Measures for Asylum-Seekers and Refugees in EU Member States, Bertelsmann Stiftung and European University Institute.

OECD (2016). Making integration work: Refugees and others in need of protection, OECD Publishing, Paris.

Penninx, R. (2009). Decentralising Integration Policies. Managing Migration in Cities, Regions and Localities, Policy Network Paper November, London: Policy Network.

Penninx, R., Kraal, K., Martiniello, M. \& Vertovec, S. (2004). Citizenship in European Cities. Immigrants, Local Politics and Integration Policies, Farnham: Ashgate Publishing.

Scholten, P. (2013). Agenda Dynamics and the Multilevel Governance of Migrant Integration: The Case of Dutch Migrant Integration Policies, Policy Sciences, 46(3), 217-236.

Scholten, P., Baggerman, F., Dellouche, L., Kampen, V., Wolf, J., \& Ypma, R. (2017). Policy innovation in refugee integration? A comparative analysis of innovative policy strategies toward refugee integration in Europe, Rotterdam: Erasmus University Rotterdam.

Schultz-Nielsen, M. L. (2017). Labour market integration of refugees in Denmark, Nordic Economic Policy Review 2017, 55-85.

Venturini, A. (2016). Case Study Italy, in Martin, I. et al, From Refugees to Workers: Mapping Labour Market Integration Support Measures for Asylum-Seekers and Refugees in EU Member States, Bertelsmann Stiftung and European University Institute. 


\section{ANNEXES}

Figure 1. Number of first residence permits issued by reason, EU-28, 2008-2017

Number of first residence permits issued by reason, EU-28, 2008-2017

(1 000 persons)

1,250

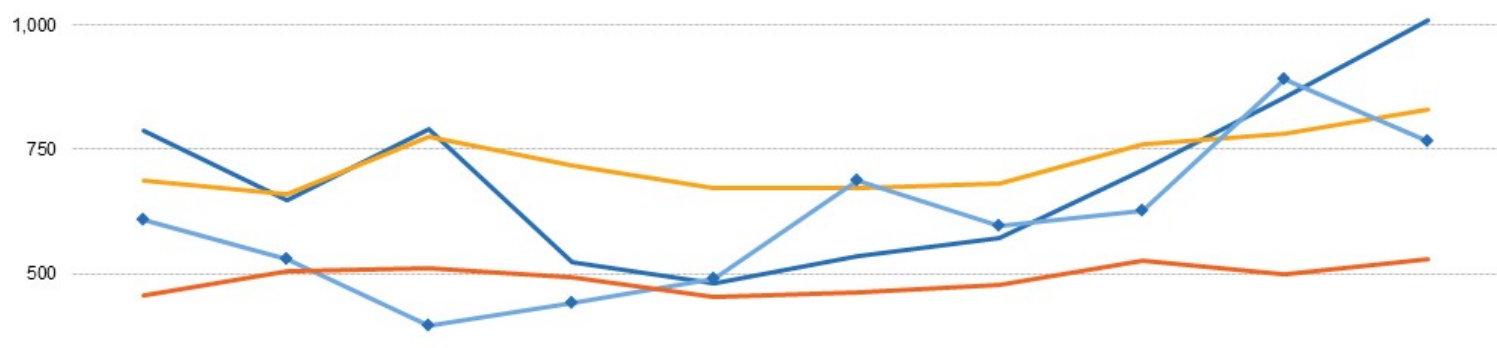

250

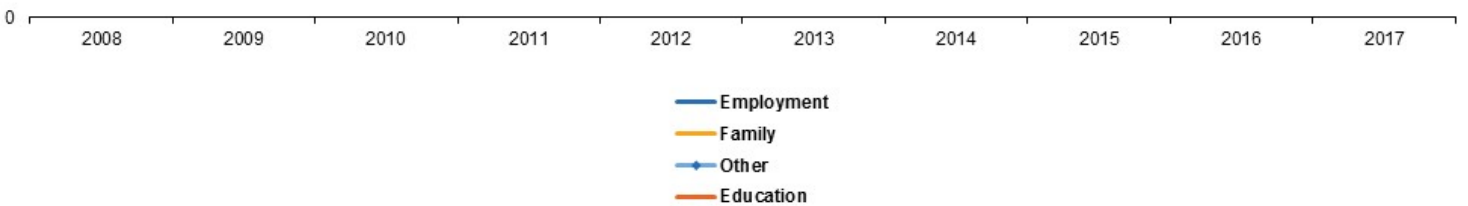

Note: EU-27 for 2008-2012. Estimate for 2008 including 2009 data for Luxembourg.

Source: Eurostat (online data code: migr_resfirst)

eurostat?

Figure 2 Percentage Foreign born in EU Member States, 2018 (1 Jan)

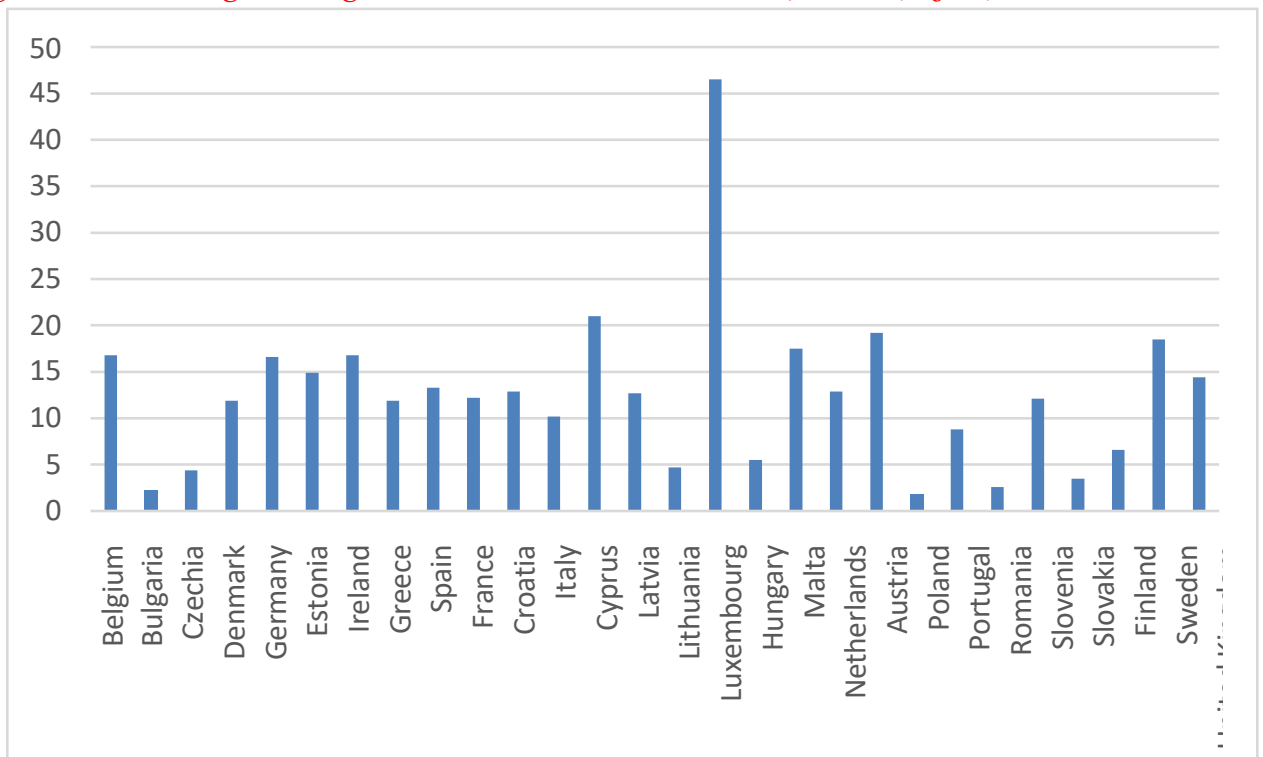

Source: https://ec.europa.eu/eurostat/statistics-

explained/index.php?title=Migration_and_migrant_population_statistics 
Figure 3 Asylum applications (non-EU9 in the EU-28 Member States, 2008-2018

Asylum applications (non-EU) in the EU-28 Member States, 2008-2018 (thousands)

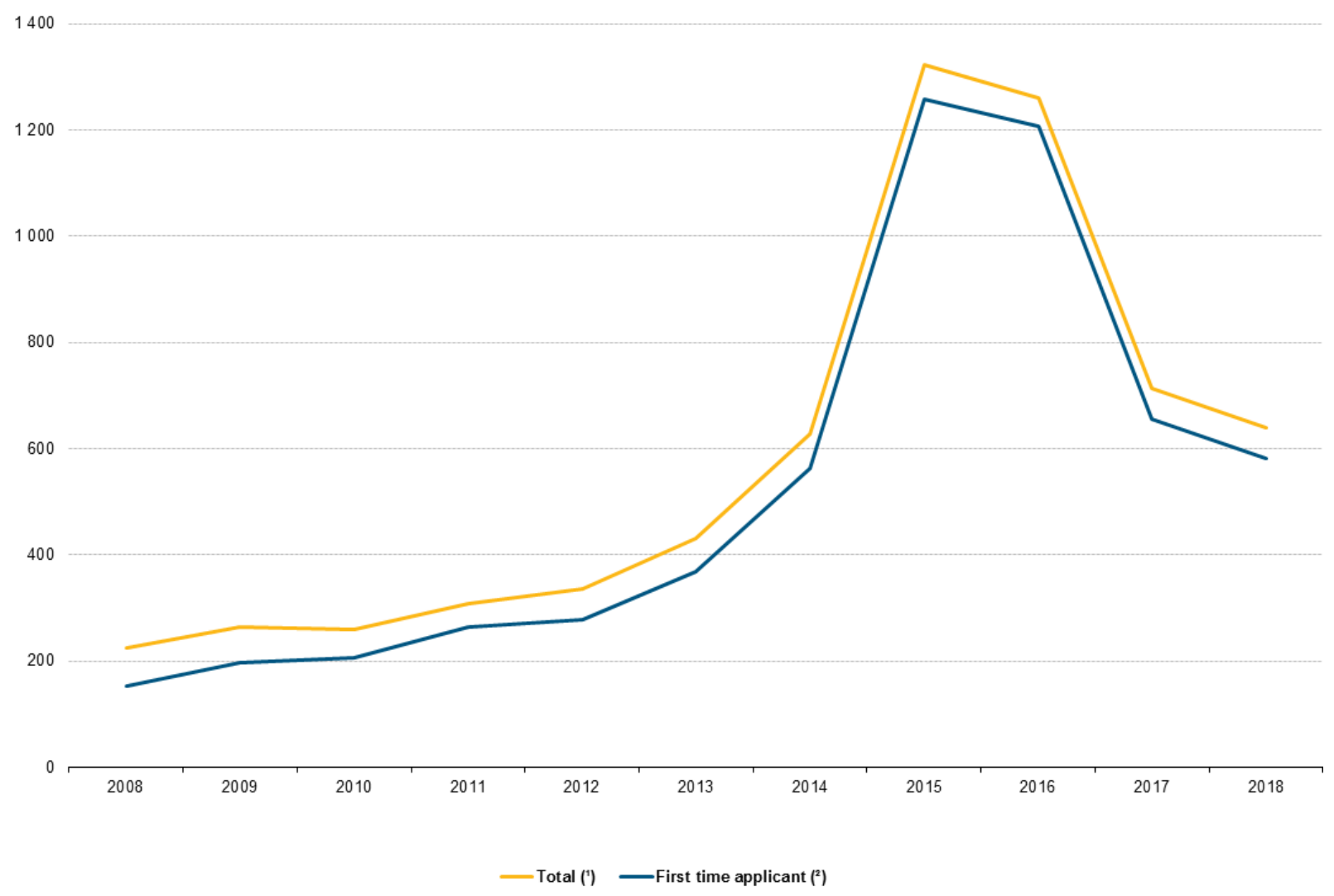

(1) 2008 - 2014: Croatia not available

(2) 2008: Bulgaria, Greece, Spain, France, Croatia, Lithuania, Luxembourg, Hungary, Austria, Romania, Slovakia and Finland not available. 2009: Bulgaria, Greece, Spain, Croatia, Luxembourg, Hungary, Austria, Romania, Slovakia and Finland not available. 2010: Bulgaria, Greece, Croatia, Luxembourg, Hungary, Austria, Romania and Finland not available. 2011: Croatia, Hungary, Austria and Finland not available. 2012: Croatia, Hungary and Austria not available. 2013: Austria not available.

Source: Eurostat (online data code: migr_asyappctza) 
Figure 4 Number of (non-EU) asylum seekers in the EU and EFTA Member States, 2017 and 2018

Number of (non-EU) asylum seekers in the EU and EFTA Member States, 2017 and 2018 (thousands of first time applicants)

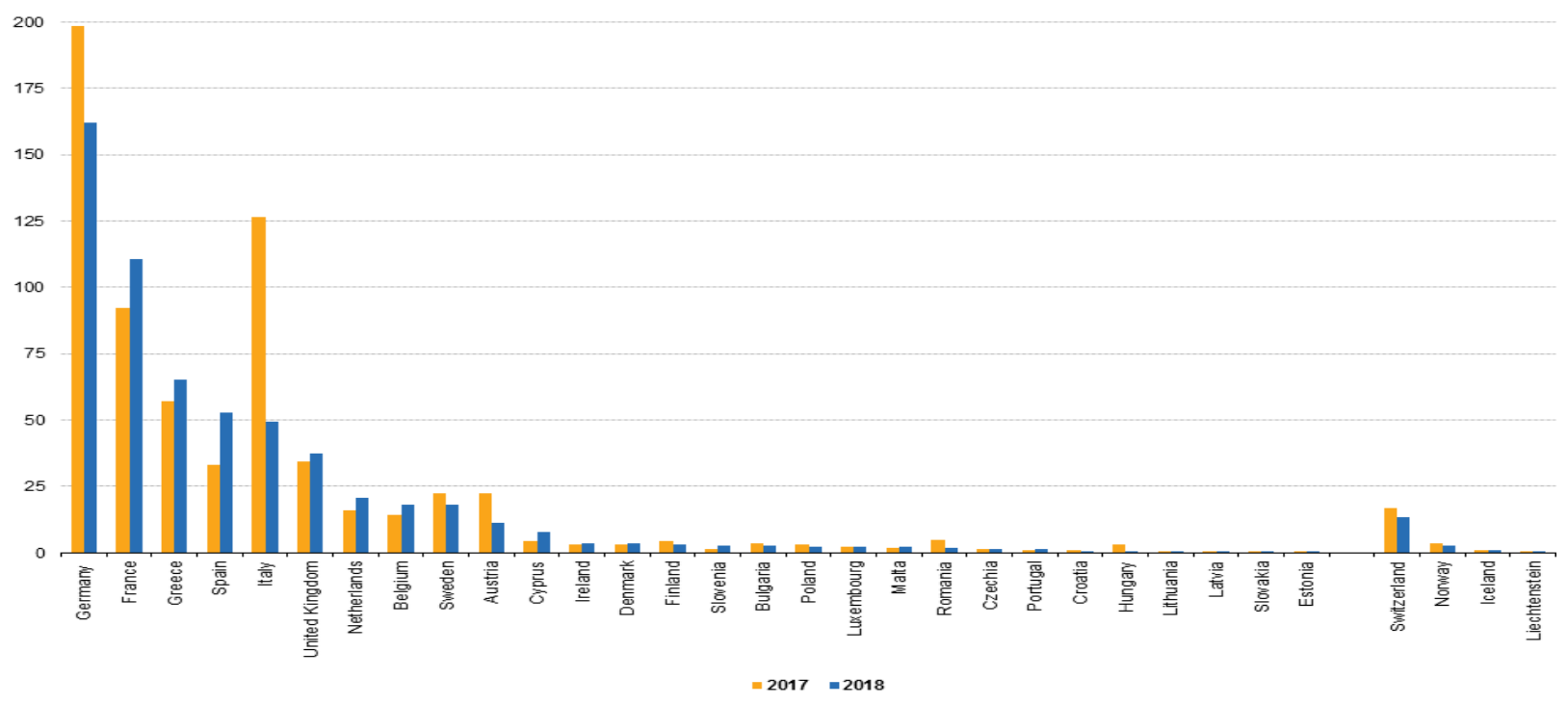


Figure 5 Distribution of first instance decision on (non-EU) asylum applications, 2018

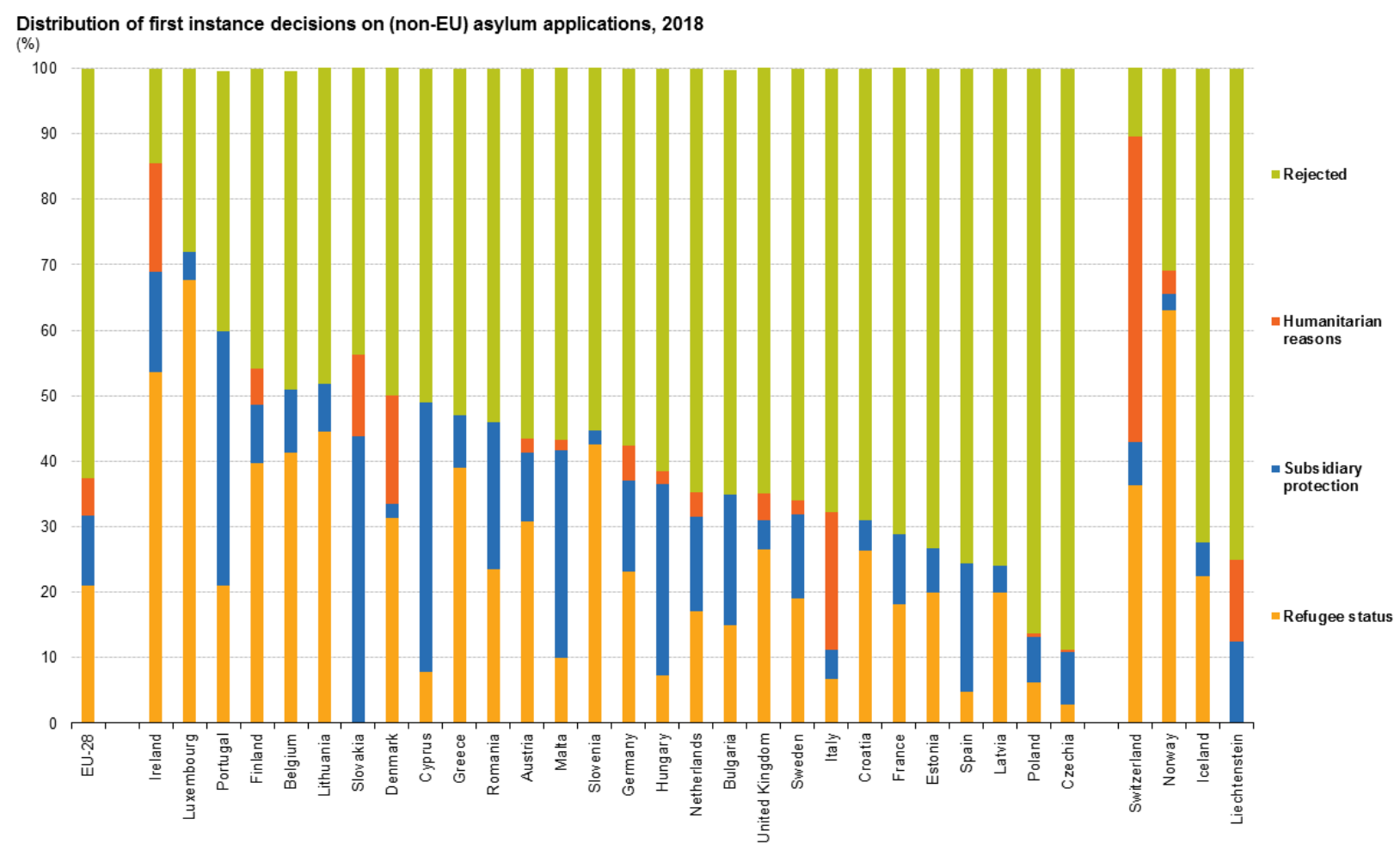

Note: due to the use of rounded figures in these calculations the sum of all age groups does not always equal $100 \%$. Source: Eurostat (online data code- migr asydcfsta)

Figure 6 Employment rate for Native born, EU born and Non-EU born by Member State 2017

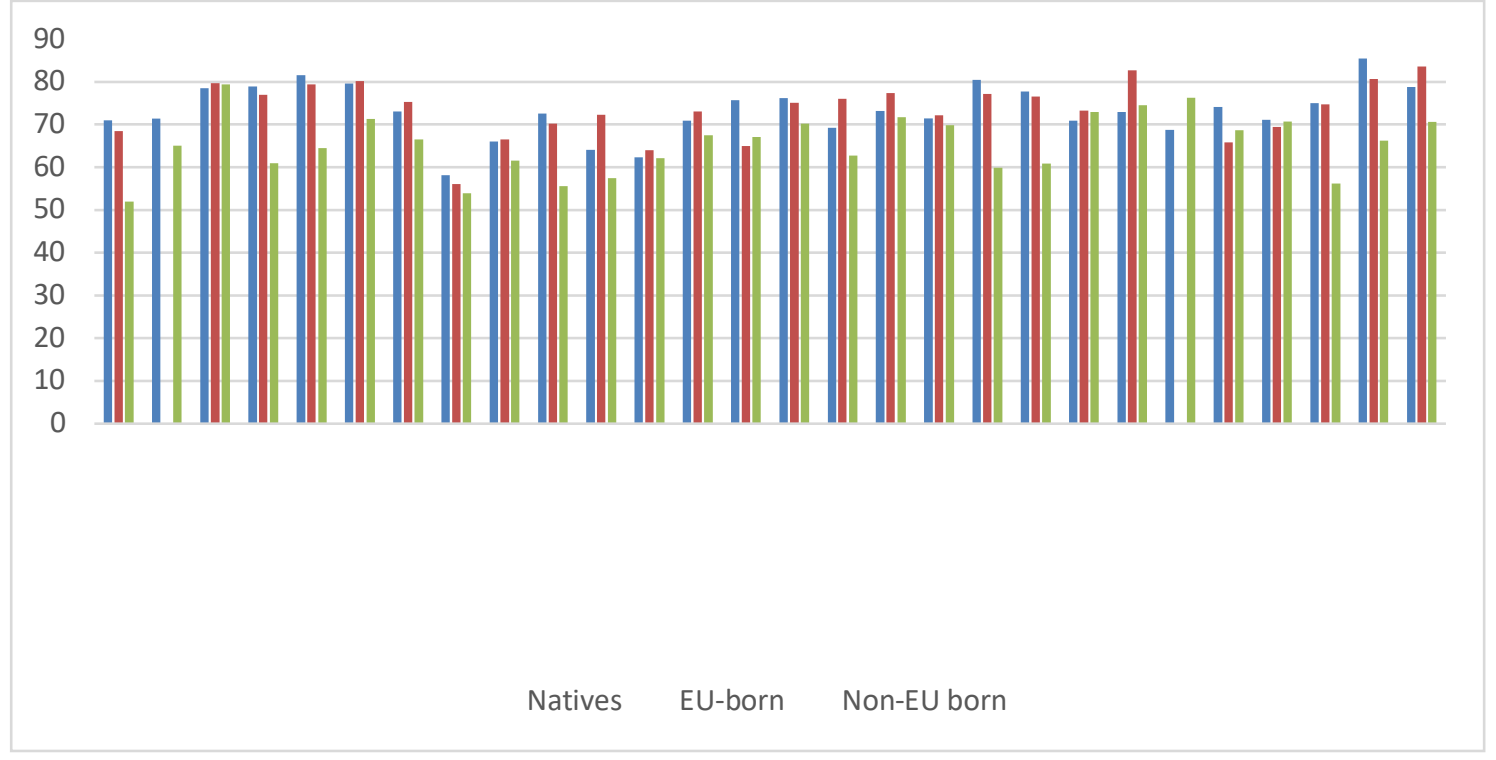

Source: https://ec.europa.eu/eurostat/statistics-explained/pdfscache/35409.pdf 
Figure 7 Trends in Employment Rate Gaps for selected EU Member States, 2006-16.

Year

25

Recent humanitarian migration

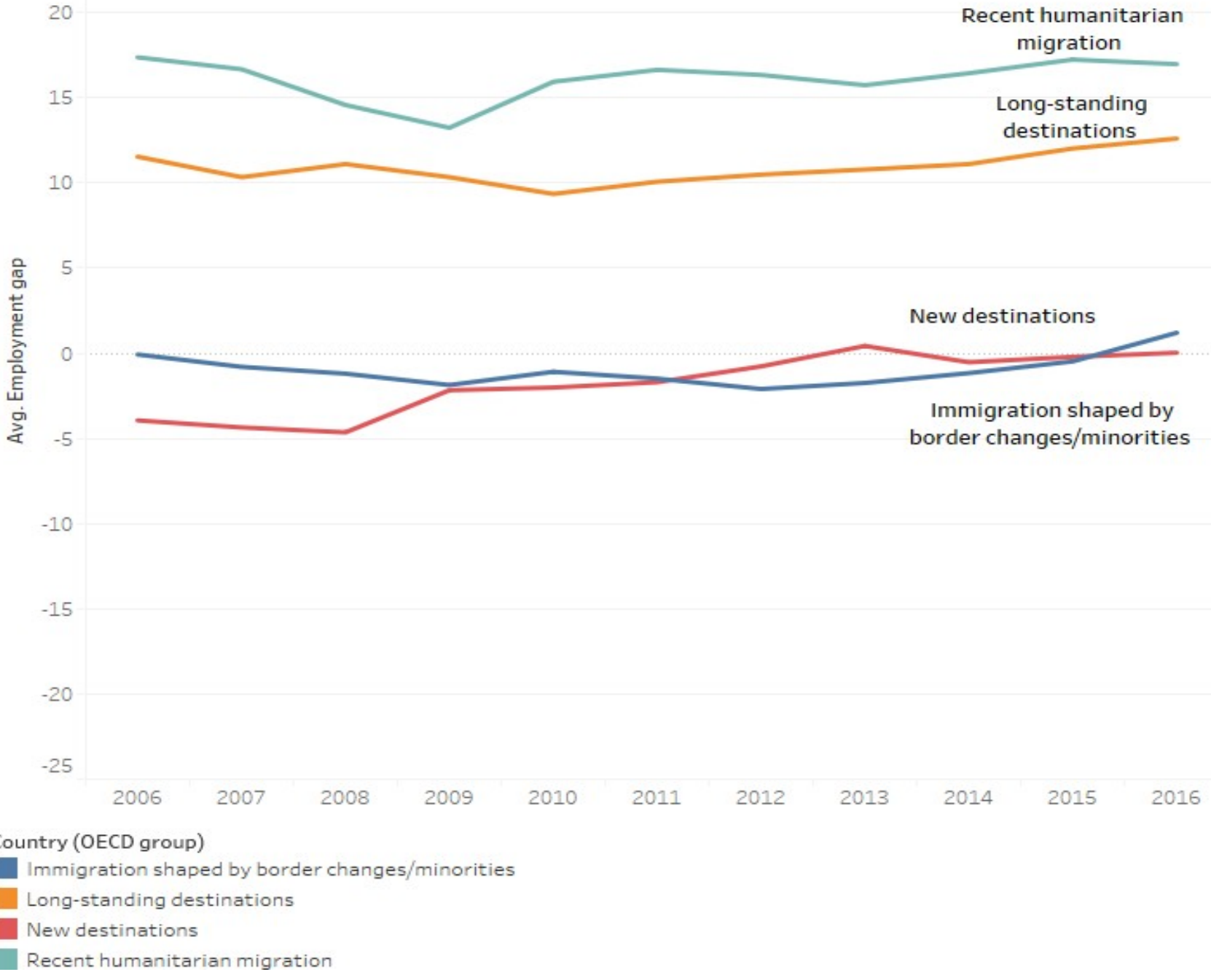

Source: European Commission 2017 
Figure 8, Mean employment rate of men/women over years since migration (YSM), Sweden

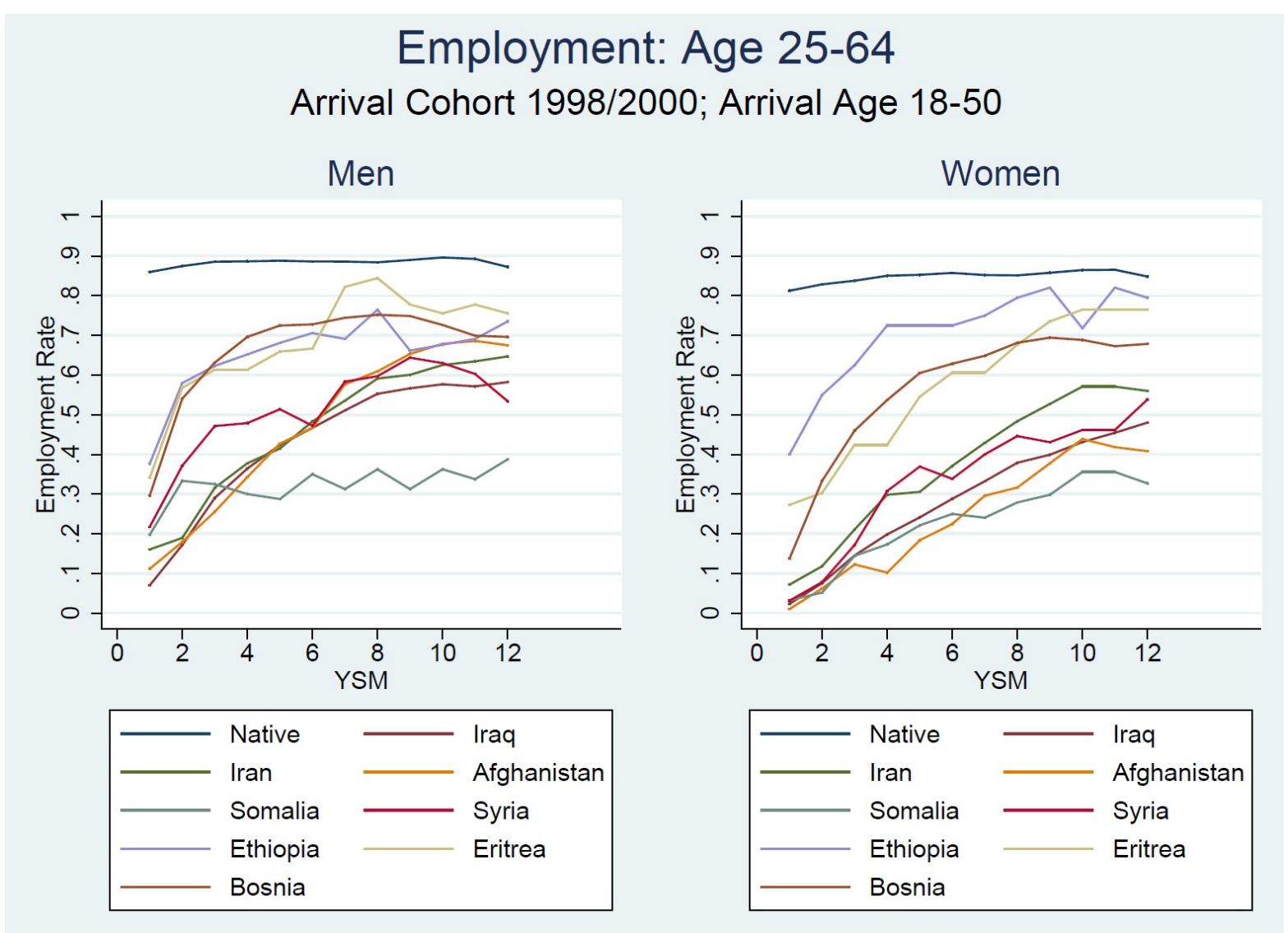

Source: Bevelander and Luik 2020. 